\title{
Sensitivity of serum C-reactive protein (CRP) levels compared to white blood cell count (WBC) as a predictor of surgical site infection in patients undergoing major surgery
}

\author{
Felix Hangandi ${ }^{*}$ and Supomo ${ }^{2}$ \\ ${ }^{1}$ Department of Surgery, ${ }^{2}$ Sub Division Thorax Cardiovascular, Department of Surgery, \\ Faculty of Medicine, Universitas Gadjah Mada/Dr. Sardjito General Hospital, Yogyakarta
}

\begin{abstract}
Early diagnosis and treatment of infections is essential in the care of the surgical patients. Rapid and appropriate diagnosis for an infection can prevent irrational use of antibiotics in the surgical care. A blood culture is a standard method to detect and identify bacteria causing the infections. However, it is time-consuming to confirm the results. Therefore, an alternative method that sensitive and specific to reduce the time necessary to confirm the laboratory report is urgently needed. The aim of this study was to compare the sensitivity and specificity of C-reactive protein (CRP) with white blood cell (WBC) count as a predictor of surgical site infection (SSI) in patients who underwent major surgery. This was a descriptive analytical study with a prospective observational design involving patients who underwent major surgery in Department of Surgery, Dr. Sardjito General Hospital, Yogyakarta between Octobers until December 2011. On the third day post operative surgery, serum CRP level and WBC were measured. In addition, bacterial culture from the surgical wound of patients who suffered SSI, according to Centers for Disease Control (CDC) criteria, was performed. Among 49 patients who involved in this study, 16 patients $(32.7 \%)$ suffered from SSI consisting 12 cases of superficial SSIs and 4 cases of deep SSIs. Among 9 patients who had an abnormal WBC count, 6 patients experienced SSI, while among 9 patients who had CRP serum levels above $8 \mathrm{mg} / \mathrm{dL}, 7$ patients suffered from SSI. The sensitivity and specificity of serum CRP levels in predicting SSI was $43.75 \%$ and $93.93 \%$, respectively. Whereas the sensitivity and specificity of WBC was $31.25 \%$ and $87.87 \%$, respectively. In conclusion, CRP is more sensitive and specific than WBC in predicting SSI in patients who underwent major surgery.
\end{abstract}

\section{ABSTRAK}

Diagnosis dan pengobatan dini infeksi merupakan tindakan penting dalam perawatan pasien bedah. Diagnosis cepat dan akurat untuk suatu infeksi dapat mencegah penggunaan antibiotik yang tidak rasional dalam perwatan bedah. Kultur darah merupakan metode standard untuk mendeteksi dan mengidentifikasi bakteri penyebab infeksi. Namun demikian, metode ini membutuhkan waktu lama untuk memastikan hasil kultur. Oleh karena itu, suatu metode alternatif yang sensitif dan spesifik untuk mengurangi waktu untuk memastikan hasil pemeriksaan laboratorium sangat dibutuhkan. Penelitian ini bertujuan untuk membandingkan sensitivitas dan spesifisitas protein C-reaktif (CRP) dengan jumlah leukosit sebagai prediktor terjadinya infeksi luka operasi (ILO) pada pasien yang menjalani bedah mayor. Penelitian ini merupakan penelitian diskriptif analitik dengan rancangan observaional prospektif yang melibatkan pasien yang menjalani

\footnotetext{
* corresponding author: felixhangadi@yahoo.com
} 


\begin{abstract}
bedah mayor di Bagian Bedah, Rumah Sakit Umum Pusat Dr. Sardjito, Yogyakarta antara bulan Oktober sampai Desember 2011. Pada hari ketiga pasca operasi, kadar CRP serum dan jumlah leukosit ditetapkan. Selain itu, kultur bakteri dilakukan pada sampel dari luka bedah dari pasien yang mengalami ILO menurut kriteria Centers for Disease Control (CDC). Dari 49 pasien yang terlibat dalam penelitian, 16 pasien $(32,7 \%)$ mengalami ILO terdiri dari 12 ILO tipe superficial dan 4 ILO tipe deep. Diantara 9 pasien yang mempunyai jumlah leukosit abnormal, 6 pasien mengalami ILO, sedangkan diantara 9 pasien yang mempunyai kadar CRP serum di atas $8 \mathrm{mg} / \mathrm{dL}, 7$ pasien mengalami ILO. Sensitivitas dan spesifisitas kadar CRP serum dalam mempredeksi ILO berturutturut adalah 43,75\% dan 93,93\%, sedangkan untuk jumlah leukosit berturut-turut adalah 31,25\% dan $87,87 \%$. Dapat disimpulkan bahwa kadar CRP lebih sensitif dan spesifik dari pada jumlah leukosit dalam mempredeksi ILO pada pasien yang menjalani bedah mayor.
\end{abstract}

Key words : C-reactive protein - serum levels - white blood cell count - major surgery - surgical site infection

\section{INTRODUCTION}

Nosocomial infections can be defined as those occurring within 48 hours of hospital admission, 3 days of discharge or 30 days of an operation. ${ }^{1}$ These infections occur worldwide and affect both developing and developed countries. Nosocomial infections are among the major causes of death and increase morbidity among hospitized patients. A study conducted by WHO (World Health Organization) in 55 hospitals of 14 countries showed an average $8.7 \%$ of hospital patients had nosocomial infection. In addition 1.4 million people worlwide suffer from infectous complication acquired in hospital. The highest frequencies of nosocomial infections were reported from hospitals in the Eastern Mediterranean (11.8\%) followed in South-East Asia Regions (10.0\%), Western Pasific regions (9.0\%) and European $(7.7 \%){ }^{2}$

A recent study found that surgical site infections (SSIs) are the most common nosocomial infections. The incidence of SSI varies from 0.5 to $15 \%$ depending on the type operation and underlaying patient status..$^{1-3}$ It is associated with a mortality rate of $3 \%$ and $75 \%$ of SSI-associated deaths are directly attributable to the SSI. ${ }^{4}$ While advances in infection control practices have been made including improved operating room ventilation, sterilization methods, barriers, surgical technique, antimicrobial prophylaxis and treatment, SSIs remain as one of the health problems that require special attention. Surgical site infections remain a substantial cause of morbidity, prolonged hospitalization and death. ${ }^{4,5}$

Early diagnosis and treatment of infections is essential in the care of the surgical patients. Rapid and appropriate diagnosis for an infection is important for an early and effective antibiotics therapy and for prevention of the inappropriate of use of broad-spectrum antibiotics, thereby minimizing the potential emergence of resistant bacterial strains. ${ }^{1}$ However in clinical practice, clinicians often have difficulties to make early appropriate diagnosis and to choose the right antibiotics. ${ }^{6}$ Sometimes, the clinical signs are secondary to non-infectious causes, such as immune system reactions, chemical or physical aggression, vasculitis or neoplasia, which may be impossible to differentiate of an infection. ${ }^{7}$

A blood culture is a standard method to detect and identify bacteria causing the infections. However, it is time-consuming to confirm the results. Therefore, an alternative diagnosis method of infections that sensitive and specific to reduce the time necessary to confirm the laboratory report is urgently needed. There 
are several biomarkers available for the diagnosis, prognosis, and therapeutic response of bacterial infections. At the present time only the white blood cell (WBC), lactate, C-reactive protein (CRP), interleukin 6 (IL-6) and IL-8, and procalcitonin (PCT) have testing platforms which provide results in the time needed. ${ }^{8-12}$

The success of a biomarker will depend on the determination of the appropriate patient populations and cut-off ranges for particular clinical conditions. ${ }^{12}$ In this study sensitivity and specificity of CRP were compare to WBC count as biomarker for SSI in patients undergoing major surgery. The WBC count is used as control due to it is probably the most commonly regognized biomarker for the bacterial infection. ${ }^{11,12}$

\section{MATERIALS AND METHODS}

\section{Subjects}

This was a descriptive analytical study with a prospective observational design. Patients were observed during hospitalization from undergoing a major surgery until 30 days post surgery. Subjects in this study were surgical patients in Department of Surgery, Dr. Sardjito General Hospital, Yogyakarta who underwent major surgery from October $30^{\text {th }}$ to Desember $31^{\text {st }}$ 2011. Samples were obtained by consecutive sampling technique with a maximum sample size of 50 patients. The inclusion criteria were the patients who undergoing major surgery, aged more than 18 years, and willing to involve in the study by signing an informed consent. Major surgery included in this study were cranitotomy, laminectomy, laparotomy, cholecystectomy, thoracotomy, cardiac surgery, rib clipping, mastectomy, soft tissue tumors, oral cavity tumors, ORIF (open reduction internal fixation), extremities amputation, open prostatectomy, orchidectomy/orchidopexy, ureterolithotomy, and pyelolithotomy. Exclusion criteria in this study were those who had been diagnosed by infection clinically before undergoing surgery, those who had major surgery due to trauma, pancreatitis, combustion or chemical substance exposure, and those who had kidney failure, HIV/AIDS, or in immunocompromised state. The protocol of this study was approved by the Health Research Ethics Committee of the Faculty of Medicine, Universitas Gadjah Mada, Yogyakarta.

\section{Procedures}

On admission to Department of Surgery to undergo major surgery, clinical examination were conducted before surgery and blood samples were taken for routine laboratory investigations including WBC count. An explanation concerning the background, objectives, benefits of the study was informed. Patients who met the inclusion and exclusion criteria were given an informed consent to be signed. After major surgery, SSI of patients were observed. Surgical site infection was defined as condition in which the fluid pus abscess or cellulitis that extends on the surgical site that appears within 30 days post surgery or 1 year in case of implant according to CDC criteria. Furthermore, blood samples were then taken again for routine laboratory examinations including CRP measurement, WBC counts and as well as blood culture. Serum CRP level of patient was measured quantitatively with an Automated High-Sensitivity CRP (hs-CRP) using Daichii reagents. White blood cell count of patients were measured using hematology analyzer Sysmex XS-800i. The WBC count value of $4.800-10.800 / \mathrm{mm}^{3}$ was considered as normal value. Blood culture was conducted in an aerobic and anaerobic condition using BACTEC 9240 automatic blood culture analyzer system (Becton Dickinson Diagnostic 
Instrument Systems, Sparks, MD, USA). Patient blood samples were secured in the BACTEC culture bottle.

\section{Statistical analysis}

Univariate analysis was used to calculate research variables. Bivariate analysis using Chi-square $\left(\div^{2}\right)$ was used to evaluate the relationship between WBC counts or CRP and SSI. Odds ratio (OR) with $95 \%$ confidence intervals $(95 \% \mathrm{CI})$ was calculated to assess the risk factors of SSI due to WBC counts or CRP. A $\mathrm{p}$ value $<0.05$ was considered to be significant.

\section{RESULTS}

During a period from October $30^{\text {th }}$ to December $31^{\text {st }} 2011$, a total of 51 patients who met inclusion and exclusion criteria were recruited. However, two patients could not continue this study due to loss of laboratory data. Therefore only 49 patients could be evaluated in this study consisting 22 male patients and 27 female patients. The ages of subjects were between 22 until 77 years old with an average of 48.2 years old. According to the type of surgical wound, the patients can be classified into patients with clean surgical wound (23 cases or $46.9 \%$ ), clean surgical wound contamination (17 cases or $34.7 \%$ ), surgical wound contamination ( 7 cases or $14.3 \%$ ) and dirty surgical wound ( 2 cases or $4.1 \%$ ).

Among 49 patients involved in this study, 16 patients suffered from SSI (TABLE 1). The SSI was found in $8(50 \%)$ patients with a clean surgical wound, 3 (18.7\%) patients with clean surgical wound contamination, 4 (25\%) patients in surgical wound contamination and 1 (6.3\%) patient in dirty surgical wound. According to sex, SSI events were observed in $5(31.3 \%)$ female patients, and $11(68.7 \%)$ in male patients. Based on patients age, the incidence of SSI was found in $1(6.2 \%)$ patient aged $21-40$ years, 12 (75\%) patients aged $41-60$ years and $3(18.6 \%)$ patient aged over 60 years.

TABLE 1. Incidenc surgical site infection among patients underwent major surgery

\begin{tabular}{lcc}
\hline Variable & Number & Percentage (\%) \\
\hline Infection & 16 & 32.7 \\
No infection & 33 & 67.3 \\
\hline & 49 & 100 \\
\hline
\end{tabular}

The most common clinical symptoms according to $\mathrm{CDC}$ criteria was redness skin around the wound $(81.3 \%)$, followed by wound wound pain $(75 \%)$, raging skin $(68.8 \%)$, aspiration of fluid (62.5\%), and purulent fluid (62.5\%). The patient complaint was commonly observed in patients suffering from superficial SSIs $(75 \%)$ with surgical wound clean type $(50 \%)$. Amonh 16 patients suffering from SSI, $7(43.7 \%)$ patients showed a positive culture of bacteria infection consisting 4 (57.1\%) patients with Pseudomonas aeroginosa, 1 (14.2\%) patient with Escherichia coli, 1 (14.2\%) patient with Staphylococcal, and 1 (14.2\%) patient (14.2\%) with P. aeroginosa and Staphylococcal.

Among 9 patients $(18.36 \%)$ who had WBC count beyond the $4.800-10.800 / \mathrm{mm}^{3}, 6(66.6 \%)$ patients experienced SSI, while $3(33.3 \%)$ of them did not. Moreover, among 9 patients who had CRP serum levels above $8 \mathrm{mg} / \mathrm{dL}, 7$ $(77.7 \%)$ patients suffered from SSI, while 2 $(22.3 \%)$ of them did not. The sensitivity and specificity of serum CRP levels in predicting SSI was $43.75 \%$ and $93.93 \%$, respectively. Whereas the sensitivity and specificity of WBC was $31.25 \%$ and $87.87 \%$, respectively. Ten patients suffering from SSI had a normal WBC count, and 8 patients suffering from SSI had normal serum CRP levels. 

white blood cell count (WBC) as a predictor of surgical site infection in patients undergoing major surgery

Relationship between WBC count or CRP and SSI is presented in TABLE 2. No significant relationship between WBC count and SSI was observed $(\mathrm{p}=0.105)$, while the relationship between CRP and SSI was statisticaly significant $(\mathrm{p}=0.001)$.

TABLE 2. The relationship between WBC count or CRP and SSI

\begin{tabular}{|c|c|c|c|c|c|c|c|c|}
\hline \multirow{3}{*}{\multicolumn{2}{|c|}{ Independent variable }} & \multicolumn{4}{|c|}{ Infection incidence } & \multirow{3}{*}{$\mathrm{X}^{2}$ count } & \multirow{3}{*}{$\mathrm{X}^{2}$ table } & \multirow{3}{*}{$\mathrm{p}$} \\
\hline & & \multicolumn{2}{|c|}{ Infection } & \multicolumn{2}{|c|}{ No infection } & & & \\
\hline & & $\mathrm{N}$ & $\%$ & $\mathrm{~N}$ & $\%$ & & & \\
\hline \multirow{2}{*}{ WBC count } & Abnormal & 5 & 55.56 & 4 & 44.44 & \multirow{2}{*}{2.63} & \multirow{2}{*}{3.841} & \multirow{2}{*}{0.105} \\
\hline & Normal & 11 & 27.50 & 29 & 72.50 & & & \\
\hline \multirow{2}{*}{ CRP level } & Abnormal & 7 & 77.80 & 2 & 22.20 & \multirow{2}{*}{10.289} & \multirow{2}{*}{3.841} & \multirow{2}{*}{0.001} \\
\hline & Normal & 9 & 22.50 & 31 & 77.50 & & & \\
\hline
\end{tabular}

OR analysis between the incidence of SSI and WBC count or serum CRP level are presented in TABLE 3. The OR analysis showed that patients who have abnormal WBC count had SSI risk of 3.295 higher than the normal one $(\mathrm{OR}=3.295$ : CI $95 \%(0.745$ to 14.574). Whereas patients who have abnormal serum CRP level had SSI risk of 12.06 time higher than the normal one $(\mathrm{OR}=12.056 ; 95 \%$ CI : 2.12 to 68.540 ).

TABLE 3. OR analysis between the incidence of SSI and WBC count or serum CRP level

\begin{tabular}{|c|c|c|c|c|c|c|}
\hline \multirow{2}{*}{\multicolumn{2}{|c|}{ Independent variable }} & \multicolumn{2}{|c|}{ SSI incidence } & \multirow{2}{*}{ OR } & \multicolumn{2}{|c|}{ CI $95 \%$} \\
\hline & & Infection & No infection & & Lower & Upper \\
\hline \multirow{2}{*}{ WBC count } & Abnormal & 5 & 4 & \multirow{2}{*}{3.295} & \multirow{2}{*}{0.75} & \multirow{2}{*}{14.57} \\
\hline & Normal & 11 & 29 & & & \\
\hline \multirow{2}{*}{ CRP level } & Abnormal & 7 & 2 & \multirow{2}{*}{12.056} & \multirow{2}{*}{2.12} & \multirow{2}{*}{68.54} \\
\hline & Normal & 9 & 31 & & & \\
\hline
\end{tabular}

Logistic regression test was used to observe the magnitude of the effect of independent variables on the dependent variable. The results, calculated by Negelkerke R Square, for WBC count and serum CRP level was 0.069 and 0.200 , respectively which means that the influence of the WBC count in the occurrence of SSI was $6.9 \%$ and the effect of serum CRP levels on the occurrence SSI was $20 \%$.

Bivariate test results between the dependent variable (wound infection) with independent variables (WBC count and serum CRP levels) showed that the number of WBC count had no significant relationship with the occurrence of SSI. If it exceeded the normal WBC count, the occurrence of SSI would have the possibility of 3.295 times greater than normal WBC count $(\mathrm{OR}=3.295:$ CI $95 \%:(0.745$ to 14.574$)(\mathrm{p}=$ 0.105). Serum CRP levels showed a significant relationship with the occurrence of SSI. In ubnormal serum CRP levels, the occurrence of SSI was 14.545 times greater than in normal serum CRP levels $(\mathrm{OR}=14.545$ : $95 \% \mathrm{CI}=$ 1.527 to 138.511 ). 
The sensitivity and specificity of WBC count comparte to serum CRP level to diagnose SSI is presented in TABLE 4. The sensitivity and specificity of WBC count to diagnose SSI were $31.25 \%$ and $87.87 \%$, respectively with the positive expected value (PPV) and negative expected value (NPV) were $55.55 \%$ and $72.50 \%$, respectively. The sensitivity and specificity of serum CRP level to diagnose SSI were $43.75 \%$ and $93.93 \%$, respectively with the PPV and NPV were $77.77 \%$ and $77.75 \%$, respectively.

TABLE 4. Sensitivity and specificity of WBC count and serum CRP level in predicting of SSI

\begin{tabular}{|c|c|c|c|c|c|c|c|c|}
\hline \multirow[b]{2}{*}{ Variable } & & \multicolumn{2}{|c|}{ SSI } & \multirow[b]{2}{*}{ Total } & \multirow{2}{*}{$\begin{array}{c}\text { Sens. } \\
(\%)\end{array}$} & \multirow{2}{*}{$\begin{array}{c}\text { Spec. } \\
(\%)\end{array}$} & \multirow{2}{*}{$\begin{array}{c}\text { PPV } \\
(\%)\end{array}$} & \multirow{2}{*}{$\begin{array}{c}\text { NPV } \\
(\%)\end{array}$} \\
\hline & & Infection & $\begin{array}{c}\text { No } \\
\text { infection }\end{array}$ & & & & & \\
\hline \multirow{3}{*}{ WBC count } & Abnormal & 5 & 4 & 9 & \multirow{3}{*}{31.25} & \multirow{3}{*}{87.87} & \multirow{3}{*}{55.50} & \multirow{3}{*}{72.50} \\
\hline & Normal & 11 & 29 & 10 & & & & \\
\hline & Total & 16 & 33 & 49 & & & & \\
\hline \multirow{3}{*}{ CRP level } & Abnormal & 7 & 2 & 9 & \multirow{3}{*}{43.75} & \multirow{3}{*}{93.93} & \multirow{3}{*}{77.77} & \multirow{3}{*}{77.75} \\
\hline & Normal & 9 & 31 & 40 & & & & \\
\hline & Total & 16 & 33 & 49 & & & & \\
\hline
\end{tabular}

\section{DISCUSSION}

In this study the use of CRP as biomarker for SSI was compared to WBC count in patients undergoing major surgery in Department of Surgery, Dr. Sardjito General Hospital, Yogyakarta. The results shoed that the incidence of SSI among patients underwent major surgery in this study was $32.7 \%$. It was hingher than previously study that conducted in the same hospital (5.6\%). ${ }^{14}$ Another study conducted in Dr. WZ Yohanes Distric Hospital, Kupang, Nusa Tenggara among patients who underwent caesarean section found that the incidence of SSI was $16.7 \% .^{15}$ While a study conducted in Jinnah Postgraduate Medical Center (JPMC), Karachi, Pakistan reported that the SSI counted as much as $7.3 \%{ }^{16}$

The commonest causative microorganism of SSI found in this study was $P$. aeruginosa followed by $E$. coli and $S$. aureus. Its were not different with the previous study that conducted in the same hospital reporting that $P$. aeruginosa was the commonest causative microorganisme of SSI. ${ }^{14}$ A multi center study conducted in Thailand reported that the three most common pathogens isolated were E. coli, S. aureus, and P. aeruginosa ${ }^{17}$ Moreover, it was reported that $P$. aeruginosa was the commonest pathogen found in both inpatient and outpatient installation at the hospital. While $P$. aeruginosa and $S$. negative coagulase were reported as the common pathogen found in the surgical ward and ICU of the hospital. ${ }^{18}$

Bivariate analysis between WBC count and SSI showed that an abnormal WBC count had the possibility of 3.295 times higher than the normal one. However, it was not statistically significant $(\mathrm{OR}=3.295 ; 95 \% \mathrm{CI}=0.745-14.574$; $\mathrm{p}=0.105)$. In contrast, serum CRP level had a significant relationship with SSI. An abnormal serum CRP level had the possibility of 12.06 
times higher than the normal one $(\mathrm{OR}=12.056$; $95 \% \mathrm{CI}=2.120-68.540 ; \mathrm{p}=0.001)$. It was indicated that serum CRP level could be a better predictor of SSI compared to WBC count. Further analysis was performed to evaluate the accuracy of determination of serum CRP level and WBC for the diagnosis of SSI. Serum CRP level was more sensitive $(43.75 \%$ versus $31.25 \%)$ and more specific $(55.55 \%$ versus $72.50 \%$ ) than WBC count for the diagnosis SSI in patients underwent major surgery.

C-reactive protein is an acute phase reactant and indicates the non-specific presence of an acute inflammatroy state. ${ }^{9,10} \mathrm{C}$-reactive protein has been extensively studied as an inflammatory biomarker and clinically utilized. Most studies agree that CRP is sensitive for bacterial infection although it lacks specificity. The exact sensitivities and specificities of CRP for the diagnosis of bacterial infections vary from study to study and therefore clinicians should interpret it's elevation in the context of other clinical factors. Current study shows a positive role for the use of CRP in diagnosing acute bacterial infection, but most authors recommend the use of CRP in combination with other more acute biomarkers. The concentration of CRP parallels the course of infection and its appropriate contemporary use will be to determine when to discontinue antibiotic therapy and monitor long term treatments. ${ }^{10-12}$

\section{CONCLUSION}

It can be concluded that serum CRP level is more sensitive and specific than WBC count in predicting SSI in patients who underwent major surgery. The sensitivity and specificity of serum CRP level are $43.75 \%$ and $93.93 \%$, respectively, whereas the sensitivity and specificity for the WBC count are $31.25 \%$ and $87.87 \%$, respectively. Further study is needed with larger samples size in order to find biomarker of infections that more sensitive and specific for early diagnosis of SSI in in patients who underwent major surgery.

\section{ACKNOWLEDGEMENTS}

Authors would like to thank Head of Department of Surgery, Dr. Sardjito General Hospital for his permission to conduct this study. We would also like to thank all subjects who have participated in this study.

\section{REFERENCES}

1. Inweregbu K, Dave J, Pittard A. Nosocomial infections. Contin Educ Anaesth Crit Care Pain 2005; 5(1): 15-8.

2. Ducel G, Fabry J and Nicolle L. Prevention of hospital-acquired infections: a practical guide, $2^{\text {nd }}$ ed. Geneva: World Health Organization, 2002.

3. Magill SS, Magill SS, Hellinger W, Cohen J, Kay $\mathrm{R}$, Bailey $\mathrm{C}$, et al. Prevalence of healthcareassociated infections in acute care hospitals in Jacksonville, Florida. Infect Control Hosp Epidemiol 2012; 33(3): 283-91.

4. Awad SS. Adherence to surgical care improvement project measures and post-operative surgical site infections. Surg Infect (Larchmt) 2012; 13(4): 234-7.

5. Anonim. Surgical site infection: prevention and treatment of surgical site infection clinical guideline. National Collaborating Centre for Women's and Children's Health (UK). London: RCOG Press, 2008.

6. Povoa P. C-reactive protein: a valuable marker of sepsis. Intensive Care Med 2002; 28(3): 235-3.

7. Kinnear FB, Kirkness CM. Advances in rapid laboratory diagnosis of infectious endophthalmitis. J Hosp Infect 1995;(30 Suppl): 253-61.

8. Simon L, Gauvin F, Amre DK, Saint-Louis P, Lacroix J. Serum procalcitonin and C-reactive protein levels as markers of bacterial infection: a systemic review and meta-analysis. Clin Infect Dis 2004; 39(2): 206-17.

9. Sierra R, Rello J, Bailen MA, Benitez E, Gordillo $\mathrm{A}$, Leon $\mathrm{C}$, et al. C-reactive protein used as an early indicator of infection in patients with systemic inflammatory response syndrome. Intensive Care Med 2004; 30(11): 2038-45. 
10. Chan YL, Liao HC, Tsay PK, Chang SS, Chen JC, Liaw SJ. C-reactive protein as an indicator of bacterial infection of adult patients in the emergency department. Chang Gung Med J 2002; 25(7) 437-45.

11. Hatherill M, Tibby SM, Sykes K, Turner C, Murdoch IA. Diagnostic markers of infection: comparison of procalcitonin with C-reactive protein and leucocyte count. Arch Dis Child 1999; 81(5): 417-21.

12. Blomkalns A. Sick or not sick? : evolving biomakers for severe bacterial infection. EMCREG 2007; 7:1-11.

13. Reny JL, Vuagnat A, Ract C, Benoit MO, Safar M, Fagon JY. Diagnosis and follow-up of infections in intensive care patients: value of C-reactive protein compared with other clinical and biological variables. Crit Care Med 2002; 30(3): 529-35.

14. Harmono S. Faktor resiko infeksi luka operasi pada pasien pasca bedah dewasa di unit bedah RSUP
Dr.Sardjito Yogyakarta [Thesis]. Yogyakarta, Universitas Gadjah Mada; 2002.

15. Rasvitri. Hubungan antara indikasi, pemrakarsa dan prosedur Caesarean section dengan terjadinya infeksi luka operasi di RSUD Prof. DR.WZ. Johannes Kupang [Tesis]. Yogyakarta: Universitas Gadjah Mada; 2009.

16. Bibi S, Channa GA, Siddiqui TR, Ahmed W. Frequency and risk factors of surgical site infections in general surgery ward of a tertiary care hospital of Karachi, Pakistan. J Infect Control 2011; v7:i3 doi: 10.3396/ijic.

17. Anonim. Pola kuman di RSUP DR Sardjito [Laporan Penelitian]. Yogyakarta: Bagian Patologi Klinik RSUP DR. Sardjito, 2011.

18. Kasatpibal N, Jamulitrat S, Chongsuvivatwong V. Standardized incidence rates of surgical site infection: a multicenter study in Thailand. Am J Infect Control 2005; 33(10): 587-94. 